\title{
Immobilization of Isocitrate Dehydrogenase on Mesoporous Silica Foam for Carbon Dioxide Capture
}

\author{
Shunxiang Xia ${ }^{1,2}$, Laibao Zhang $^{3}$, and Enjelia Veony ${ }^{2}$ \\ ${ }^{1}$ Department of Bioproducts and Biosystems Engineering, University of Minnesota, Saint Paul, MN 55108, USA \\ ${ }^{2}$ Department of Petroleum Engineering, University of Houston, Houston, TX 77023, USA \\ ${ }^{3}$ Department of Chemical Engineering, Louisiana State University, Baton Rouge, LA 70803, USA
}

\begin{abstract}
Carbon capture can be realized effectively through isocitrate dehydrogenase reaction and the reaction rate was strongly affected by the environmental parameters such as $\mathrm{pH}$ and temperature. Enzyme immobilization was conducted to improve the enzyme stability during the capture process. By simply adsorbing enzyme on the surface of mesoporous silica foam, enzyme stability against temperature, $\mathrm{pH}$ and shear stress was improved. The immobilization process can be completed in 5 mins, and $0.87 \mathrm{U}$ enzyme activity was kept for each gram of immobilization material. After 10 cycles, more than 50 percent of enzyme activity remained. The reusability and improved stability made immobilized ICDH a better candidate for large-scale application of carbon capture.
\end{abstract}

\section{Introduction}

Isocitrate dehydrogenases (ICDHs) from different species show vast varieties in their kinetics, structure, stability, and more important, cofactor-dependence [1]. The NADdepend ICDHs are (a4b4) heterooctamers, existing in the mitochondria of eukaryotes cells with a function of decarboxylation in the tricarboxylic acid (TCA) cycle [2]. Different from NAD-dependent ICDHs, NADP-dependent ICDHs usually possess the dimeric structure, with the molecule weight of subunits ranging from 40 to $57 \mathrm{kDa}$ [3]. NADP-dependent ICDHs exist in both prokaryotes and eukaryotes, located in the cytosol, peroxisomes, and mitochondria, with a function of biosynthesis of fatty acids and amino acids. ICDHs was initially believed to only possess the decarboxylation function, while the discovery of reductive TCA cycle revealed its carboxylation activity [4]. In reductive TCA cycle, ICDH catalyzes the step that one mole of isocitrate is synthesized from one mole of ketoglutarate and carbon dioxide. By manipulating the system $\mathrm{pH}$, extensive carbon capture can be realized through ICDH reaction with high reaction selectivity and energy efficiency.

The high stability and possible reusability are necessary for the economic feasibility of the enzymatic process. Besides the application of protein engineering to improve the enzyme propensity by modifying the protein Ketoglutarate, NADPH, NADP+, D-Isocitrate, sodium bicarbonate, 2-(N morpholino) ethanesulfonic acid (Mes), $\mathrm{N}, \quad \mathrm{N}$-Bis(2-hydroxyethyl) glycine(Bicine), 2(Cyclohexylamino)ethanesulfonic acid (Ches), isocitrate consequence, some apparently older techniques, such as immobilization are widely applied as a simple but powerful approach to increase the enzyme activities and reduction of inhibition in the system. Considering the various native characterizations of enzyme and different immobilization proposes, hundreds of immobilization protocols were reported, while properly screening of the ideal immobilization material for the target enzyme is still an exciting goal in our project.

Mesoporous materials, especially mesoporous silica foam (MSF), possess a highly ordered structure with nanometer pore size, therefore providing a high surface area for enzyme adsorption [5]. As an immobilization material, mesoporous silicates exhibit high chemical, thermal resistance and inertia, and by controlling the amphiphilic block copolymer and surfactant selfassemblies, the pore size could be controlled between $2 \mathrm{~nm}$ to $50 \mathrm{~nm}$ to meet different requirements. Enzymes can directly bind the MSF through the hydrophilic attraction of the hydroxy group of the surface of MSF, and for advanced application, various active groups modified on the surface of MSF can additionally facilitate enzyme loading with strong or specific binding [6].

\section{Material and Methods}

\subsection{Material}

dehydrogenase (ICDH) from porcine heart (EC 1.1.1.42) and mesostructured silica foam (MSF, 560979)were purchased form Sigma Chemical Co. (St. Louis, USA). Unless specially mentioned, all other reagents and solvents 
used in the experiments were of the highest grade commercially available.

\subsection{Activity assay of free enzyme}

In the decarboxylation reaction, the assay mixture contained $10 \mathrm{mM}$ isocitrate, $2 \mathrm{mM}$ NADP+, $40 \mathrm{mM}$ $\mathrm{MgCl} 2$ and free enzyme in $1 \mathrm{~mL}$ of buffer. With prepaid time, the mixture was centrifuged quickly and the increase of NADPH in the supernatant was detected by absorbance at $340 \mathrm{~nm}$, and one unit of decarboxylation activity was defined as $1 \mu \mathrm{mol}$ of NADPH formed per min. The carboxylation activity was detected in the same way except the mixture was composed of $20 \mathrm{mM}$ sodium ketoglutarate, $3 \mathrm{mM}$ NADPH, $40 \mathrm{mM} \mathrm{MgCl} 2,35 \mathrm{mM}$ $\mathrm{NaHCO} 3$ and one unit of carboxylation activity was defined as $1 \mu \mathrm{mol}$ of NADPH oxidized per min. Mes buffers with $\mathrm{pH}$ values from 5.0 to 7.0; Bicine buffer with $\mathrm{pH} 8.0$ and Ches buffer with $\mathrm{pH} 9.0$ were used in this work.

\subsection{Enzyme immobilization}

The buffer solution was used to dilute the enzyme solution to the final protein concentration as $100 \mathrm{mg} / \mathrm{ml}$, and then MSF (1 g) was added in $1 \mathrm{ml}$ solution. After mild shaking at $200 \mathrm{rpm}$ for $5 \mathrm{mins}$, the solid was recovered by centrifugation and washed with $5 \mathrm{ml}$ buffer solution for three times. The immobilized enzyme was kept with MES buffer $\mathrm{pH} 7.0$ at $4{ }^{\circ} \mathrm{C}$.

\subsection{Activity assay of immobilized enzyme}

The carboxylation assay mixture contained $20 \mathrm{mM}$ sodium ketoglutarate, $3 \mathrm{mM}$ NADPH, $40 \mathrm{mM} \mathrm{MgCl} 2,35 \mathrm{mM}$ $\mathrm{NaHCO} 3$ and $40 \mathrm{mM} \mathrm{MgCl}$, $2 \mathrm{mg}$ immobilized enzyme (protein weight) per $1 \mathrm{~mL}$ of $\mathrm{pH} 7$ buffer. The mixture was shaken at room temperature at $200 \mathrm{rpm}$. Samples were periodically taken and were centrifuged before NADPH concentration was detected by absorbance at $340 \mathrm{~nm}$. One unit of special carboxylation activity was defined as $1 \mu$ mol of NADPH consumed per min.

\subsection{Detection of leakage}

To ascertain the non-leachable character of enzyme adsorbed on the MSF, the leakage investigation was performed in the following way during activity assays: Reaction solution with immobilized enzyme was shaken at room temperature at $200 \mathrm{rpm}$, and after $5 \mathrm{mins}$, the mixture was centrifuged and the concentration of protein in supernatant was detected with Bradford method. Then the immobilized enzyme was added into fresh reaction solution for another cycle.

\subsection{Enzyme stability tests}

Free or immobilized ICDH was kept in buffer solution for predetermined time, and the remaining activity of the enzyme for carboxylation was detected with same methods as described for enzyme activity assay. Several factors such as $\mathrm{pH}$, temperature, stirring rate were applied to the system to indicate the improvement of enzyme stability against these factors.

\section{Results and discussion}

\subsection{The effect of pH on enzyme activity}

The specific activity of enzyme at different $\mathrm{pH}$ was detected and showed in Figure 1. Both carboxylation and decarboxylation activities were detected for ICDH from porcine heart and the optimum $\mathrm{pH}$ for decarboxylation and carboxylation was 8 and 6 respectively. The highest specific activity for carboxylation was achieved at $\mathrm{pH} 6$ as $0.45 \mathrm{U} / \mathrm{mg}$, and a decline of carboxylation activity was observed with increasing $\mathrm{pH}$ value. Since the direction of the reaction was determined by the net reaction rate for both carboxylation and decarboxylation, carbon capture (carboxylation) was more favorable at acid condition [7].

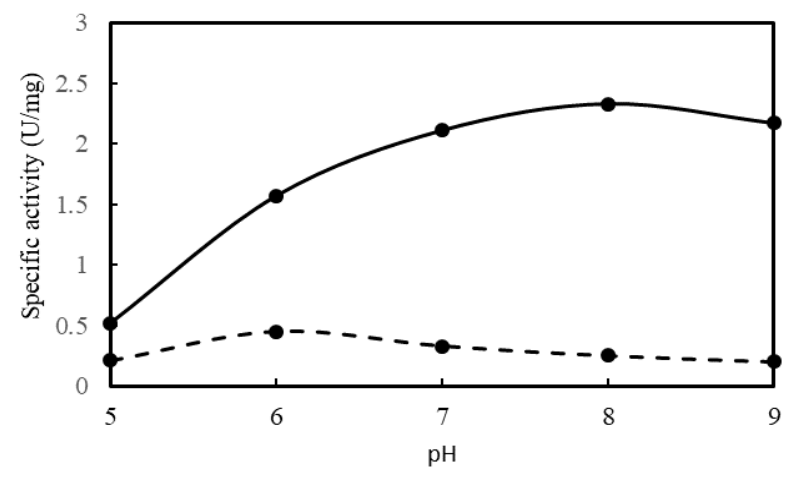

Fig. 1. The pH profiles of ICDH from porcine heart (Solid line: decarboxylation. Dash line: carboxylation).

\subsection{The effect of temperature on enzyme activity}

The manipulation of the reaction temperature is a simple and effective way to improve the performance of enzyme. Generally, higher temperature translates to higher activity. According to molecular dynamics, a higher temperature increases the kinetic energy of molecules and the probability of achieving the activation energy of reaction when molecules collide with each other. The increase in temperature also enhances the number of collisions of enzyme and substrate per unit time, resulting in the rise of the reaction rate. A $50-100 \%$ increase is observed in the enzyme activity with a 10-degree $\mathrm{C}$ increase in temperature. However, as fragile protein, every enzyme has an optimum temperature. When the temperature is higher than the optimum value, the three-dimensional shape of enzyme becomes thermodynamically unstable, resulting in loss of activity [8]. The effect of temperature on enzyme activity was represented in Figure 2. The figure showed that ICDH had an optimum temperature around $45{ }^{\circ} \mathrm{C}$. At this temperature, the specific activity of carboxylation was $1.21 \mathrm{U} / \mathrm{mg}$ at $\mathrm{pH} 6$, exhibiting three 
times increase from the room temperature. A decline of specific activity was observed for the temperatures beyond $45^{\circ} \mathrm{C}$.

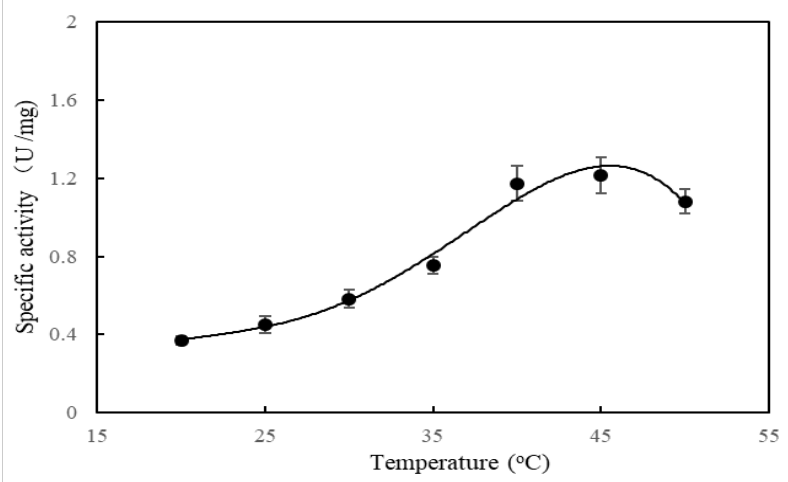

Fig. 2. The effect of temperature on enzyme specific activity.

\subsection{The effect of incubation time on performance of enzyme immobilization}

As both the external and internal pore structure of MSF accessed high surface area for protein adsorption, the initial diffusion of enzyme molecules in bulk solution resulted in a quick adsorption on the external surface of MSF. The completion of adsorption on the internal surface required a longer time as slower internal diffusion. Many references have pointed out that performance of adsorption heavily depended on the pore size of the MSF [9]. In this study, the mean diameter of MSF cell window (15 nm) was a little bit larger than the diameter of enzyme molecules $(10 \mathrm{~nm})$, which can benefit the diffusion process and prevent too much leakage. The adsorption rate of ICDH on the MSF was plotted in Figure 3.

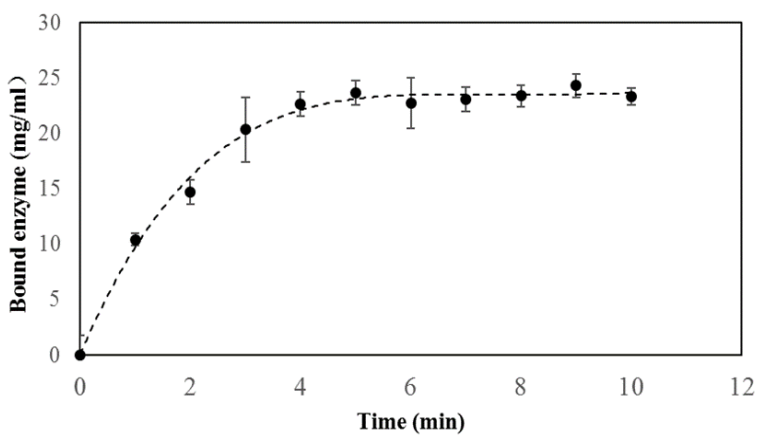

Fig. 3. The amount of bound enzyme with MSF with incubation time.

Based on the data, the adsorption process was rapid and was completed in 5 mins. In the first minute, $10.4 \mathrm{mg}$ of enzyme was adsorbed, indicating a quick adsorption on the external surface of the material. Then the adsorption rate decreased to $4 \mathrm{mg} / \mathrm{min}$. The amount of bound enzyme reached $23 \mathrm{mg} / \mathrm{ml}$. During this period, most adsorption seemed to happen on the internal surface of MSF and the adsorption rate was limited by the diffusion of the enzyme into the internal room of MSF. After this stage, the amount of bound enzyme kept constant and the rate was smaller than $0.2 \mathrm{mg} / \mathrm{ml} / \mathrm{min}$. This slight adsorption occurred in the place covered with a small cell window, where it was hard for the enzyme to enter.

\subsection{The effect of enzyme concentration on performance of enzyme immobilization}

According to references, bulk enzyme concentration was one of critical parameters affecting the performance of physical adsorption. In this study, the influence of protein concentration was first studied and reported in Table 1.As reported in the Table 1, increasing the concentration of initial enzyme resulted in a more enzyme adsorption, but a lower protein yield. With $20 \mathrm{mg} / \mathrm{ml}$ enzyme, $18.72 \mathrm{mg}$ of enzyme was bound on the MSF, representing a $93.60 \%$ of protein yield. While doubling the initial enzyme concentration can only get $2 \mathrm{mg}$ more enzyme adsorbed, and the protein yield decreased to $51.08 \%$. Increasing enzyme concentration beyond $20 \mathrm{mM}$ showed limited improvement of adsorption, as most of the surface was covered with enzyme molecule. Besides adsorption amount, activity value of immobilization gave a better evaluation of its performance. The maximum measure activity was $0.87 \mathrm{U}$ per gram of MSF with $200 \mathrm{mg} / \mathrm{ml}$ initial protein concentration and the value decreased to $0.75 \mathrm{U}$ with $20 \mathrm{mg} / \mathrm{ml}$ protein. The overall activity yield was around $15 \%$ in this study since a large part of the enzyme lost the access to the substrate due to conformation limitation originated from immobilization.

Table 1. The effect of enzyme concentration on protein yield and activity yield

\begin{tabular}{llllll}
\hline $\begin{array}{l}\text { Initial } \\
\text { protein } \\
(\mathrm{mg} / \mathrm{ml})\end{array}$ & $\begin{array}{l}\text { Bound } \\
\text { protein } \\
(\mathrm{mg} / \mathrm{ml})\end{array}$ & $\begin{array}{l}\text { Protein } \\
\text { yield } \\
(\%)\end{array}$ & $\begin{array}{l}\text { Expected } \\
\text { activity } \\
(\mathrm{U} / \mathrm{ml})\end{array}$ & $\begin{array}{l}\text { Measured } \\
\text { activity } \\
(\mathrm{U} / \mathrm{ml})\end{array}$ & $\begin{array}{l}\text { Activity } \\
\text { yield } \\
(\%)\end{array}$ \\
\hline 20 & 18.72 & 93.60 & 4.93 & 0.75 & 15.10 \\
40 & 20.43 & 51.08 & 5.38 & 0.79 & 14.65 \\
80 & 22.87 & 28.59 & 6.03 & 0.80 & 13.32 \\
100 & 23.51 & 23.51 & 6.20 & 0.82 & 13.18 \\
200 & 25.80 & 12.90 & 6.81 & 0.87 & 12.75 \\
\hline
\end{tabular}

Where expected activity was calculated by multiplying the amount of bond protein with specific activity (carboxylation) of free enzyme

Protein yield $=$ bound protein $/$ initial protein

Activity yield $=$ measured activity $/$ expected activity

\subsection{Characterization of immobilized enzyme}

In most cases, the enzyme needs to be evaluated after immobilization due to the changing of kinetic behavior. After the process of immobilization, internal structural changes and restricted access to the active site would affect the kinetic constants Km, Vmax of the enzyme. In order to evaluate the performance of immobilization, the kinetics constants of free ICDH from the porcine heart and adsorbed ICDH with MSF was detected and shown in Table 2.

Table 2. Free and immobilized enzyme characterization 


\begin{tabular}{llll}
\hline Samples & $\mathrm{kcat}[\mathrm{S}-1]$ & $\mathrm{Km}[\mu \mathrm{M}]$ & $\begin{array}{l}\mathrm{kcat} / \mathrm{Km} \\
{[\mathrm{mM}-1 \mathrm{~S}-1]}\end{array}$ \\
\hline Free ICDH & 0.25 & 17.4 & 14.65 \\
$\begin{array}{l}\text { immobilized } \\
\text { ICDH }\end{array}$ & 0.04 & 70.4 & 0.53 \\
\hline
\end{tabular}

For adsorbed enzyme, the kcat/Km value for NADPH was $0.53 \mathrm{mM}-1 \mathrm{~S}-1,28$ times lower than that of free enzyme. The decline of catalytic efficiency was due to both kcat (14.6\%) and increased value of Km (4 times). The increased value indicated a stronger mass-transfer limitation between the substrate and immobilized enzymes, and enzyme denature during process attributed to the declining value of kcat.

\subsection{Leakage of immobilized enzyme}

When applied physical adsorption for enzyme immobilization, the principal driving forces include hydrogen bonding, Van Der Waals, electrostatic forces and hydrophobic or hydrophobic interaction. Since these forces are affected strongly by the reaction conditions such as temperature/pH alterations, enzyme leakage is expected during the catalytic process.

To evaluate the leakage of immobilized enzyme, the relative enzyme activity and retain enzyme concentration were recorded and shown in Figure 4 at room temperature and $\mathrm{pH} 7$. After ten cycles, about $55 \%$ of total enzyme activity was lost via both a gradual loss of binding protein $(\sim 31 \%)$ and enzyme inactivation $(\sim 24 \%)$. Both binding enzyme concentration and activity declined quickly during the first three cycles, representing a fast leakage and denature of the enzyme binding on the outside surface of the MSF. Then, a mild decline occurred, indicating that the denature and leakage also happened on the enzyme adsorbed on the inside surface of the carrier. Shear force was thought as the primary reason for the leakage and denature of immobilized enzyme, since high stirring rate resulted in a quicker decline of activity. In practice, the leakage of ICDH may be more severe with additional existence of fluctuation of temperature and $\mathrm{pH}$. Modification of the surface of the carrier to form stronger covalent binding between enzyme and MSF can be helpful, but it may also cause the reducing of enzyme loading level.

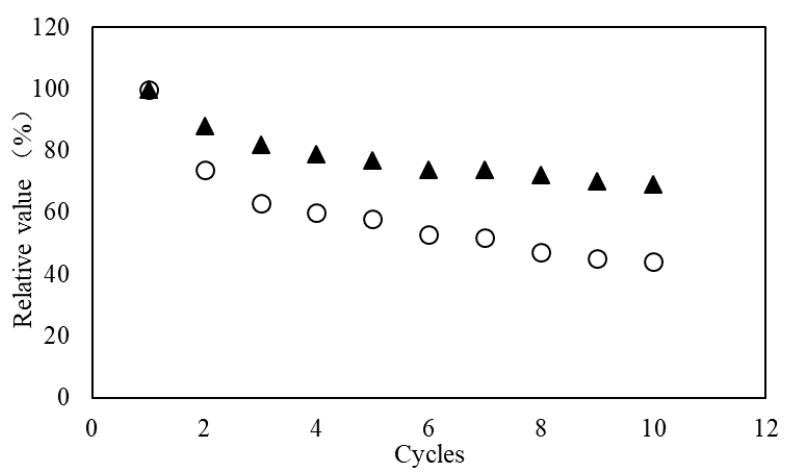

Fig. 4. Enzyme activity and retain concentration with multiple reaction cycles (circle: relative enzyme activity; triangle: relative enzyme concentration).

\subsection{Stability of immobilized enzyme}

Improvement of enzyme stability is one of the primary proposes of enzyme immobilization. As the conformation of enzyme is limited by the scaffold, immobilized enzymes show more resistance to harsh conditions. The comparison of free and immobilized enzyme stability against temperature, $\mathrm{pH}$ and shear stress was conducted and showed in Figure 5.

a
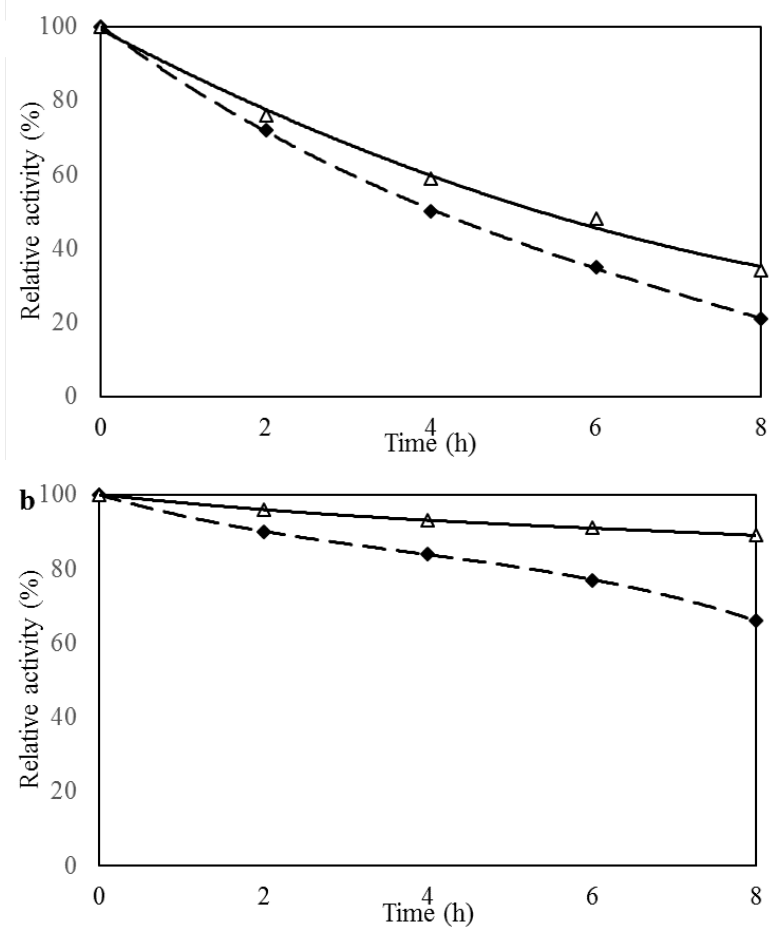

c

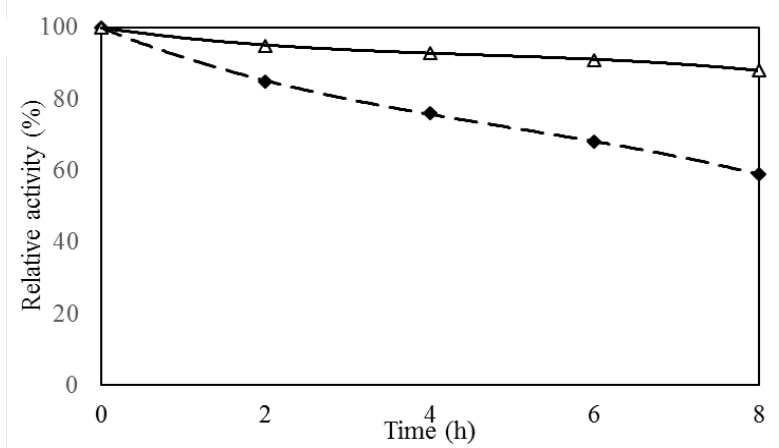

Fig. 5. The effect of immobilization on enzyme stability against a temperature $\left(55^{\circ} \mathrm{C}\right)$; b. $\mathrm{pH}(6)$ and c. shear stress (1000 rpm) (Diamond: free enzyme; Triangle: Immobilized enzyme).

As ICDH possesses more activity at higher temperature, conducting carbon capture with ICDH at higher temperature can benefit the capture rate. The advantage of immobilization was apparent at $55{ }^{\circ} \mathrm{C}$ : the half lifetime (t1/ 2) of immobilized ICDH was around 6 hours, higher than that of the free enzyme (4 hours).

Besides the thermo-stability, the stability of ICDH against $\mathrm{pH}$ was also critical for efficient carbon capture [10]. In this design, the carbon capture was conducted under acidic conditions $(\mathrm{pH} 6)$ for better reaction rate. In 
Figure 5 (b), the free enzyme possessed poor stability at $\mathrm{pH} 6$, as the halftime was only 8 hours. After immobilization, the halftime was increased to 18 hours.

In the end, the stability of enzyme against shear stress was evaluated. When enzyme was exposed to the flow of reactor, the shear force is often regarded as a cause of protein denature. Many references have pointed out the severe enzyme activity loss with a high shear force [11]. Similar to thermo-denature, the loss of activity caused by shear stress is considered as irreversible. In practice, immobilization can limit the conformation change of enzyme, therefore increases the enzyme stability against shear force. In Figure 5(c), For free enzyme, 15\% enzyme activity was lost in the first two hours, and only $59 \%$ remained after the total 8-hour incubation at $1000 \mathrm{rpm}$. In this case, immobilization can be helpful and only $12 \%$ activity was lost after 8 hours.

By adsorbing enzyme on the surface of MSF, high stability of enzyme was achieved, bringing benefits for enhancing reaction intensity and more room of manipulation.

\section{Conclusion}

In conclusion, ICDH immobilization was realized with MSF adsorption to improve enzyme stability. For each gram of MSF, $23 \mathrm{mg}$ of ICDH can be adsorbed, remaining about $0.87 \mathrm{U}$ of carboxylation activity. After immobilization, enzyme stability against temperature, $\mathrm{pH}$ and shear stress was improved significantly. Although some enzyme leakage was observed, more than half of enzyme activity remained after 10 cycles.

\section{References}

1. A. Nekrutenko, M. Hillis, C. Patton, D. Bradley and J. Baker, Mol. Biol. Evol 15, 1674-84 (1998)

2. H. Sugden and A. Newsholme, Biochem. J. 150, 10511 (1975)

3. S. Gálvez and P. Gadal, Plant Sci 105, 1-14 (1995)

4. H. Steen, T. Lien and K. Birkeland, Arch. Microbiol 168, 412-20 (1997)

5. I. Ravikovitch and V. Neimark, Langmuir 18, 155060 (2002)

6. A. Stein, Adv. Mater. 15, 763-75 (2003)

7. S. Xia, B. Frigo-Vaz, X. Zhao, J. Kim and P. Wang, Biochem. Biophys. Res. Commun. 452, 147-50 (2014)

8. C. Mateo, M. Palomo, G. Fernandez, M. Guisan and R. Fernandez, Enzyme Microb. Technol 40, 1451-63 (2007)

9. M. Hartmann and D. Jung, J. Mater. Chem, 20, 844$57(2010)$

10. S. Xia, P. Wang and J. Kim, Greenhouse Gases: Science and Technology 5, 102-07 (2015)

11. R. Thomas and D. Biotechnol Lett. 33, 443-56 (2011) 